\title{
Levels of engagement in primary health care professionals: a comparative study in two Brazilian municipalities
}

\author{
Níveis de engagement em profissionais da atenção primária à saúde: estudo comparativo em dois \\ municípios brasileiros
}

\author{
Niveles de engagement en profesionales de la atención primaria a la salud: estudio comparativo en dos \\ municipios brasileños
}

\begin{abstract}
Luciano Garcia Lourenção' (1) Albertina Gomes da Silva² ${ }^{2}$ (i) Márcio Andrade Borges ${ }^{3}$ (1)
\end{abstract}

1. Universidade Federal do Rio Grande. Rio Grande, RS, Brasil.

2. Faculdade de Medicina de São José do Rio Preto. São José do Rio Preto, SP, Brasil. 3. Damásio Educacional. Vitória, ES, Brasil.
Corresponding author:

Luciano Garcia Lourenção.

E-mail: lucianolourencao.enf@gmail.com

Submitted on 01/05/2019.

Accepted on 05/07/2019.

DOI: 10.1590/2177-9465-EAN-2019-0005

\begin{abstract}
Objective: To evaluate the levels of engagement of Primary Health Care professionals in two municipalities. Methods: A descriptive study was carried out with 238 health professionals who work in the Primary Care services of two municipalities in the state of São Paulo. The engagement dimensions of the professionals were investigated through the Utrecht Work Engagement Scale. Results: Female predominance (82.8\%), age under 40 years (52.9\%). Median working time in primary care of three (municipality A), four years (municipality B). Significant difference in levels of engagement in both municipalities. Community health agents presented mean scores in all dimensions. Significant difference in levels of engagement according to professional category in all dimensions. Conclusion and implications for practice: Municipal health professionals with $100.0 \%$ coverage by the Family Health Strategy tend to have higher levels of engagement. Nurses presented greater engagement; community health workers reached lower levels than other professionals did. Engagement is an indicator that contributes to the evaluation of the workforce in the Primary Health Care services and can be used to direct strategies that improve the levels of dedication, absorption and vigor of the professionals, benefiting the organization of the primary care services.
\end{abstract}

Keywords: Engagement at Work; Primary Health Care; Health promotion; Family Health Strategy; Unified Health System.

\section{Resumo}

Objetivo: Avaliar os níveis de engagement de profissionais da atenção primária em saúde de dois municípios. Métodos: Estudo descritivo realizado com 238 profissionais de saúde que atuam nos serviços de Atenção Primária de dois municípios do estado de São Paulo. As dimensões de engagement dos profissionais foram investigadas através da Utrecht Work Engagement Scale. Resultados: Predomínio do sexo feminino (82,8\%), idade inferior a 40 anos $(52,9 \%)$. Tempo mediano de atuação na atenção primária de três (município A), quatro anos (município B). Diferença significante dos níveis de engagement nos dois municípios Agentes comunitários de saúde apresentaram escores médios em todas dimensões. Diferença dos níveis de engagement segundo categoria profissional significante em todas dimensões. Conclusão e implicações para a prática: Profissionais de município com 100,0\% de cobertura pela Estratégia Saúde da Família tendem a ter maiores níveis de engagement. Enfermeiros apresentaram engagement maior; Agentes comunitários de saúde alcançaram níveis mais baixos que os demais profissionais O engagement é um indicador que contribui para a avaliação da força de trabalho nos serviços de Atenção Primária à Saúde e pode ser empregado para direcionar estratégias que melhorem os níveis de dedicação, absorção e vigor dos profissionais beneficiando a organização dos serviços de atenção primária.

Palavras-chave: Engajamento no Trabalho; Atenção Primária à Saúde; Promoção da Saúde; Estratégia Saúde da Família; Sistema Único de Saúde.

\section{Resumen}

Objetivo: Evaluar los niveles de engagement de profesionales de la Atención Primaria en Salud (APS) de dos municipios. Métodos: Estudio descriptivo realizado con 238 profesionales de salud de APS en el estado de São Paulo. Las dimensiones de engagement de los profesionales fueron investigadas a través de la Utrecht Work Engagement Scale. Resultados: Predominio del sexo femenino (82,8\%), edad inferior a 40 años $(52,9 \%)$. Tiempo medio de actuación en la APS de tres (municipio A), cuatro años (municipio B). Diferencia significante de los niveles de engagement en los dos municipios. Los agentes comunitarios de salud presentaron escores medios en todas las dimensiones. Diferencia de los niveles de engagement según categoría profesional significante en todas las dimensiones. Conclusión e implicaciones para la práctica: Profesionales de municipio con $100,0 \%$ de cobertura por la Estrategia Salud de la Familia tienden a tener mayores niveles de engagement. Enfermeros presentaron mayor compromiso; agentes comunitarios de salud alcanzaron niveles más bajos que los demás profesionales. $\mathrm{E}$ engagement es un indicador que contribuye a la evaluación de la fuerza de trabajo en APS y puede ser empleado para dirigir estrategias que mejoren los niveles de dedicación, absorción y vigor de los profesionales, beneficiando la organización de APS.

Palabras clave: Compromiso en el trabajo; Atención Primaria a la Salud; Promoción de la Salud; Estrategia Salud de la Familia; Sistema Único de Salud. 


\section{INTRODUCTION}

In Brazil, after the promulgation of the Federal Constitution of 1988 and the regulation of the Unified Health System (UHS) in 1990 , the challenge of reorganizing Primary Health Care (PHC) actions arose. In this context, in 1994 the Family Health Strategy (FHS) emerged as a model for organizing health actions in the first level of health care in the UHS. ${ }^{1-3}$

Over the years, the FHS has gained importance and prominence in the government's agenda, which has invested in this attention model, consolidating it as a structurer of the municipal health systems and the PHC model in Brazil. ${ }^{1}$

This care model recommends that the work be performed by a multiprofessional team, consisting of a doctor, nurse, nursing assistant or technician and community health agents (CHA). All professionals must work in a 40-hour workweek in a territory with defined scope and registered population. ${ }^{3-4}$

The National Policy of Primary Care, published in 2006 and reformulated in 2017, defines the FHS as the main strategy to expand and consolidate basic care in Brazil, becoming the preferred contact point and the gateway to a network of services and of universal access. ${ }^{4-5}$ These changes have influenced the adoption of new positions, guidelines and proposals that range from the training of health professionals to the implementation of care practices to the population, passing through the commitment of the managers. ${ }^{6}$

In this perspective, the performing in the $\mathrm{PHC}$ must go beyond the technical capacity of the team and requires that the workers identify themselves with a work proposal that demands initiative, creativity and vocation for community activities and/or in a group, seeking to meet the needs of the population..$^{2-5}$

Therefore, the workforce becomes essential to increase the responsiveness of health services inserted in the first level of care.

According to the contemporary literature, engaged professionals are essential for the proper functioning of organizations, present better performance and guarantee greater efficiency, resolution and productivity. ${ }^{7-9}$

Engagement is a recent concept, linked to positive psychology and characterized by three dimensions: vigor, dedication and absorption. It is related to a cognitive state of well-being and worker satisfaction, which presents energy and identification with work. ${ }^{10-13}$

Vigor is related to high levels of energy and resilience, willingness to invest efforts, to not easily fade and to persist in the face of difficulties. Professionals with high vigor present a lot of energy, becoming more productive. ${ }^{11,12,14}$

The dedication is related to a sense of meaning for work, to feel enthusiastic and proud of the work activity, feeling inspired and challenged by the work. Professionals with high dedication feel enthusiastic and tend to be more committed to work activity. ${ }^{11,12,14}$
Absorption is related to the immersion of the professional at work, who have difficulties to detach themselves. Professionals with high levels of absorption are so involved with work that they do not perceive time passing. ${ }^{11,12,14}$

A study carried out in Açores, Portugal, with primary care nurses identified high levels of engagement among professionals, especially nurses, who had children and had a longer working time. ${ }^{15}$

In Brazil, studies with $\mathrm{PHC}$ professionals pointed to high levels of worker engagement ${ }^{16-17}$, surpassing the indexes presented by other Brazilian professional groups as pediatric medical residents. ${ }^{18}$ However, some groups presented lower rates, such as vector control agents, workers who are younger and single, evidencing a compromise in the relation of these workers. ${ }^{16}$

According to the literature, the implementation of activities considered significant for $\mathrm{PHC}$ professionals contributes to the development of engagement among the team, resulting in positive working relationships, better job performance and greater job satisfaction. ${ }^{19}$

In this context, knowing the levels of engagement among primary health care professionals may support the implementation of reorganization actions of the Family Health teams' work processes, contributing to the improvement of the work of professionals, enhancing productivity, and the assistance offered to users.

The study aimed to evaluate the levels of engagement of primary health care professionals in two Brazilian municipalities.

\section{METHOD}

Descriptive, correlational and cross-sectional study, carried out in two municipalities in the state of São Paulo, Brazil, in the year of 2015, with a non-probabilistic, convenience sample, which included 238 professionals from the Family Health teams.

The first municipality (Municipality A) is located in the north of the state of São Paulo, $452 \mathrm{~km}$ from the capital. It is a large municipality and, according to the Brazilian Institute of Geography and Statistics, has an estimated population of 438,354 inhabitants. The municipality is the headquarters of the XV Regional Health Division, the largest in the state of São Paulo, and a reference in health care.

Organizationally, the municipality is divided into five Districts of Health. At the time of the study, the municipality had 15 units of Family Health, with 30 teams, responsible for covering $24 \%$ of the population of the municipality.

The second municipality (Municipality $B$ ) is located in the western region of the state, $596 \mathrm{~km}$ from the capital. It is a small municipality, with a population of 33,707 inhabitants. The municipality is a reference center in the health area for nine municipalities in the Nova Alta Paulista region. In the structuring of the local health model, Primary Care is performed by four Family Health units, with ten teams and coverage of $100 \%$ of the population of the municipality. 
To collect data, was used an instrument with sociodemographic and professional questions, such as profession, gender, age and time of action in primary care; and the Brazilian version of the Utrecht Work Engagement Scale (UWES), validated by Vazques et al. ${ }^{20}$, consisting of 17 questions, which comprise the dimensions of absorption, dedication and vigor, as well as a general score. ${ }^{14}$

The answers to the UWES questions are given on a likert scale of seven points, being: $0=$ never; 1 = almost never; 2 = sometimes; 3 = regularly; 4 = frequently; 5 = almost always; 6 = always. The calculation of the scores was done by the arithmetic mean of the answers of the professionals to the questions that compose each dimension, ranging from zero to six. ${ }^{14}$

In order to measure vigor, the items related to energy and resilience, effort capacity and persistence of professionals are considered: 1. In my job, I feel full (filled) of energy; 4. At work, I feel myself with strength and vigor (vitality); 8 . When I get up in the morning, I feel like going to work; 12 . I can continue working for long periods of time; 15. In my job, I am a mentally resilient (versatile) person; 17. At work, I am persistent even when things are not going well.

Dedication is measured by five questions related to enthusiasm and pride in work, feeling of inspiration and meaning of work to the worker, such as: 2. I think the work I do is full of meaning and purpose; 5 . I am enthusiastic about my work; 7. My work inspires me; 10. I am proud of the work I do; 13. For me, my job is challenging. ${ }^{14,20}$

The measurement of the absorption is made by the questions related to the immersion of the professional in the work, who gets disconnected from everything around: 3. "Time flies" when I am working; 6 . When I am working, I forget everything that goes on around me; 9 . I feel happy when I work hard; 11. I feel involved in the work I do; 14. "I get carried away" by my work; 16. It is difficult to disconnect from work.

The general score corresponds to the arithmetic mean of the answers of all questions on the UWES scale. ${ }^{14-15}$

The consistency of the data was evaluated by Cronbach's Alpha Coefficient. The calculations of the engagement dimension scores were performed according to the statistical model proposed in the UWES - Utrecht Work Engagement Scale. After the calculation of the scores of each dimension, the values obtained were interpreted according to the decoding of the Preliminary Manual UWES, being: 0 to $0.99=$ Very Low; 1 to 1.99 $=$ Low; 2 to $3.99=$ Medium; 4 to $4.99=$ High; 5 to $6=$ Very High. ${ }^{14}$

The comparison of the distribution of sociodemographic characteristics of the professionals was performed by the chisquare test and, for the comparisons of the mean scores of the UWES dimensions, the F-test was used in the analysis of variance (ANOVA), considering a level of significance of 95\% $(p<0.05)$. Data analysis was performed with the Statistical Package for Social Sciences (SPSS), version 20.0.
The study was approved by the Research Ethics Committee of the institution, with Opinion No. 460,331, dated November 12 , 2013. All participants signed the Informed Consent Term.

\section{RESULTS}

A total of 238 professionals participated in the study, of which $173(72.7 \%$ ) were from municipality A and 65 (27.3\%) from municipality $\mathrm{B}$. There was a prevalence of female professionals $(82.8 \%)$, aged less than 40 years $(52.9 \%)$. The median age of the professionals was 36 years.

The median time of performance in the $\mathrm{PHC}$ was three years in the municipality $A$ and four years in the municipality $B$; in the latter, the number of professionals with more time in the $\mathrm{PHC}$ was significantly higher than in the municipality $\mathrm{A}(p=0.050)$.

The Cronbach's Alpha Coefficient values observed were: 0.872 for the Dedication dimension questions; 0.795 for the Absorption dimension; 0.869 for the Vigor dimension; 0.940 for the General Score questions; and 0.967 among all dimensions of engagement, indicating reliability of the results.

Table 2 shows the results of the evaluation of levels of engagement for each municipality and for the total sample, according to the dimensions of UWES: vigor, dedication, absorption and overall score. There was a significant difference in levels of engagement presented by professionals from both municipalities. While the professionals of the municipality $A$ presented average levels, in the municipality $B$ the professionals presented high levels in all dimensions.

As shown in Table 3, community health agents presented average levels of engagement in all dimensions; the nurses presented a high level of absorption, while the other professionals had average levels in this dimension. The difference in levels of engagement according to the professional category was significant in all dimensions.

Table 4 presents the evaluation of the levels of engagement according to the sociodemographic characteristics of the professionals of the two municipalities. In city A, average levels of engagement for all dimensions were found between community health agents, female professionals, in the age group of 18 to 39 years and with three years or more of performance in PHC. Nurses had higher levels of engagement than other professionals. There was a significant difference between levels of engagement and professional category; vigor and time acting in $\mathrm{PHC}$.

In the municipality $B$, the doctors and nurses presented very high levels of absorption; community health agents and professionals with up to two years of performance in $\mathrm{PHC}$ had an average level of absorption; professionals aged 18 to 28 years presented medium levels in all dimensions. There was a significant difference between professional category and levels of dedication, absorption and overall score. 
Table 1. Sociodemographic characteristics of Primary Health Care professionals in the cities studied. São Paulo, Brazil, 2018.

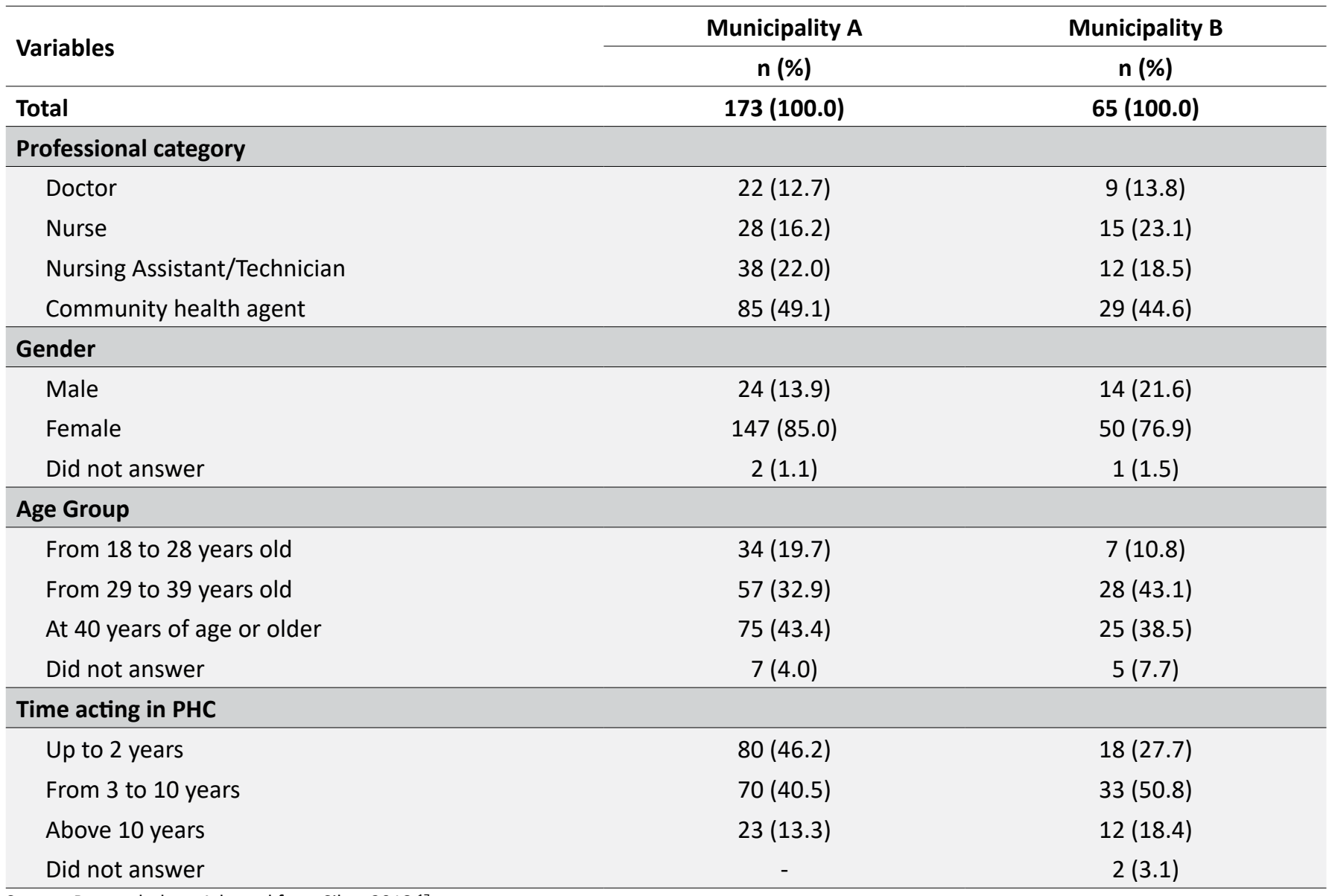

Source: Research data. Adapted from Silva, 2018. ${ }^{17}$

Table 2. Levels of engagement of Primary Health Care professionals. São Paulo, Brazil, 2018.

\begin{tabular}{lcccc}
\hline & $\begin{array}{c}\text { Dedication } \\
\text { Mean }( \pm \mathbf{s d})\end{array}$ & $\begin{array}{c}\text { Absorption } \\
\text { Mean }( \pm \mathbf{s d})\end{array}$ & $\begin{array}{c}\text { Vigor } \\
\text { Mean }( \pm \mathbf{s d})\end{array}$ & $\begin{array}{c}\text { Overall score } \\
\text { Mean }( \pm \mathbf{s d})\end{array}$ \\
\hline Municipality A & $3.8( \pm 1.5)^{\mathrm{a}}$ & $3.6( \pm 1.4)^{\mathrm{a}}$ & $3.9( \pm 1.4)^{\mathrm{a}}$ & $3.8( \pm 1.3)^{\mathrm{a}}$ \\
Municipality B & $4.6( \pm 1.2)^{\mathrm{b}}$ & $4.2( \pm 1,1)^{\mathrm{b}}$ & $4.4( \pm 1.0)^{\mathrm{b}}$ & $4.4( \pm 1.0)^{\mathrm{b}}$ \\
Total & $4.0( \pm 1.4)^{\mathrm{b}}$ & $3.8( \pm 1.3)^{\mathrm{a}}$ & $4.0( \pm 1.3)^{\mathrm{b}}$ & $3.9( \pm 1.3)^{\mathrm{a}}$ \\
p-value & $<0.001$ & 0.004 & 0.006 & 0.001 \\
\hline
\end{tabular}

Source: Research data. sd: standard deviation. ${ }^{\text {a }}$ Medium level of engagement. ${ }^{\mathrm{b}}$ High level of engagement.

\section{DISCUSSION}

The results of this study pointed out that the professionals of the small municipality, in which the FHS was integrally adopted as policy guiding the actions and services of primary care presented levels of engagement significantly higher than the professionals of the large municipality, where the implantation of the FHS possibly prioritized socioeconomically disadvantaged communities in an attempt to expand access to PHC services.
In this context, it is common for the confrontation of socio-sanitary conditions found in poor communities to cause psychological distress to professionals, compromising their levels of dedication, absorption and vigor. ${ }^{21}$

According to the literature, the difference in levels of engagement among professional categories, such as that observed in this study, may be related to the levels of professional autonomy and decision-making power. ${ }^{9,22}$ 
Table 3. Levels of engagement, according to sociodemographic characteristics of Primary Health Care professionals. São Paulo, Brazil, 2018.

\begin{tabular}{|c|c|c|c|c|}
\hline Variables & $\begin{array}{l}\text { Dedication } \\
\text { Mean }( \pm s d)\end{array}$ & $\begin{array}{l}\text { Absorption } \\
\text { Mean ( } \pm s d)\end{array}$ & $\begin{array}{c}\text { Vigor } \\
\text { Mean ( } \pm s d)\end{array}$ & $\begin{array}{l}\text { Overall score } \\
\text { Mean }( \pm s d)\end{array}$ \\
\hline \multicolumn{5}{|l|}{ Professional category } \\
\hline Doctor & $4.5( \pm 1.4)^{b}$ & $3.9( \pm 1.4)^{\mathrm{a}}$ & $4.1( \pm 1.2)^{b}$ & $4.2( \pm 1.2)^{\mathrm{b}}$ \\
\hline Nurse & $4.6( \pm 1.2)^{\mathrm{b}}$ & $4.5( \pm 1.0)^{\mathrm{b}}$ & $4.5( \pm 1.1)^{b}$ & $4.5( \pm 1.0)^{\mathrm{b}}$ \\
\hline Nursing Assistant/Technician & $4.5( \pm 1.2)^{\mathrm{b}}$ & $3.9( \pm 1.2)^{\mathrm{a}}$ & $4.3( \pm 1.2)^{b}$ & $4.2( \pm 1.1)^{b}$ \\
\hline Community health agent & $3.5( \pm 1.5)^{\mathrm{a}}$ & $3.4( \pm 1.3)^{\mathrm{a}}$ & $3.6( \pm 1.4)^{\mathrm{a}}$ & $3.5( \pm 1.3)^{\mathrm{a}}$ \\
\hline $\mathrm{p}$-value & $<0.001$ & $<0.001$ & $<0.001$ & $<0.001$ \\
\hline \multicolumn{5}{|l|}{ Gender } \\
\hline Male & $4.3( \pm 1.5)^{\mathrm{b}}$ & $3.8( \pm 1.4)^{\mathrm{a}}$ & $4.1( \pm 1.3)^{\mathrm{b}}$ & $4.1( \pm 1.3)^{\mathrm{b}}$ \\
\hline Female & $4.0( \pm 1.4)^{b}$ & $3.8( \pm 1.3)^{\mathrm{a}}$ & $3.9( \pm 1.3)^{\mathrm{a}}$ & $3.9( \pm 1.3)^{\mathrm{a}}$ \\
\hline$p$-value & 0.305 & 0.855 & 0.232 & 0.461 \\
\hline \multicolumn{5}{|l|}{ Age group } \\
\hline From 18 to 28 years old & $3.9( \pm 1.5)^{\mathrm{a}}$ & $3.7( \pm 1.2)^{\mathrm{a}}$ & $3.8( \pm 1.2)^{\mathrm{a}}$ & $3.8( \pm 1.2)^{\mathrm{a}}$ \\
\hline From 29 to 39 years old & $4.0( \pm 1.5)^{\mathrm{b}}$ & $3.7( \pm 1.5)^{\mathrm{a}}$ & $3,9( \pm 1.4)^{\mathrm{a}}$ & $3.9( \pm 1.4)^{\mathrm{a}}$ \\
\hline At 40 years of age or older & $4.2( \pm 1.4)^{b}$ & $4.0( \pm 1.2)^{b}$ & $4.2( \pm 1.2)^{b}$ & $4.1( \pm 1.2)^{b}$ \\
\hline $\mathrm{p}$-value & 0.421 & 0.167 & 0.153 & 0.173 \\
\hline \multicolumn{5}{|l|}{ Time acting in PHC } \\
\hline Up to 2 years & $4.1( \pm 1.5)^{b}$ & $3.9( \pm 1.3)^{\mathrm{a}}$ & $4.2( \pm 1.3)^{b}$ & $4.1( \pm 1.2)^{b}$ \\
\hline From 3 to 10 years & $3.9( \pm 1.4)^{\mathrm{a}}$ & $3.7( \pm 1.4)^{\mathrm{a}}$ & $3.8( \pm 1.4)^{\mathrm{a}}$ & $3.8( \pm 1.3)^{\mathrm{a}}$ \\
\hline Above 10 years & $4.1( \pm 1.4)^{b}$ & $3.9( \pm 1.3)^{\mathrm{a}}$ & $4.0( \pm 1.3)^{b}$ & $4.0( \pm 1.3)^{\mathrm{b}}$ \\
\hline$p$-value & 0.558 & 0.400 & 0.089 & 0.253 \\
\hline
\end{tabular}

Source: Research data. sd: standard deviation. ${ }^{\mathrm{a}}$ Medium level of engagement. ${ }^{\mathrm{b}} \mathrm{High}$ level of engagement.

The significantly lower levels of engagement presented by the community health agents show the presence of factors that compromise the work performance of these professionals.

Studies indicate that the existence of geographical and cultural barriers, precarious labor ties, low wages, reduced opportunities for development, low social recognition and lack of compatible training, high levels of violence and precarious socioeconomic conditions in communities can interfere with the health of $\mathrm{CHA}$ and compromise the ability to meet medical and social demands throughout the Family Health team, as CHA represent an important link between the health needs of the community and the health team. ${ }^{23-26}$

In this context, it is important that the managers value the work of the $\mathrm{CHA}$, investing in the creation of career plans for these workers and encouraging the search for professional qualification/ education. Qualified professionals with greater critical capacity may develop greater labor engagement, integrating and interacting more effectively with the other members of the Family Health team.
In addition, it is imperative to implement internal continuing education programs that can solve doubts and help the $\mathrm{CHA}$ overcome the difficulties found in the performance of the attributions established by the National Policy of Primary Care; especially socio-demographic, cultural, environmental, epidemiological and sanitary diagnosis of the territory they work in; and the development of activities to promote health and to prevent diseases and injuries prevalent in the territories. ${ }^{4}$

Likewise, the lower levels of engagement among young professionals ( 18 to 38 years old) and with a performing time in the $\mathrm{PHC}$ between three and 10 years, show that these professionals may present difficulties in the face of adverse situations due to poor working conditions, interpersonal relationship and emotional load, especially in poor communities in peripheral regions. These results contribute to professional turnover and compromise of the service's resoluteness. . $^{21,25-26}$

Considering that, although labor conditions may alter levels of engagement ${ }^{9}$, these results reinforce the need for actions towards professional valorization and promotion of the workers' 
Table 4. Levels of engagement, according to sociodemographic characteristics of Primary Health Care professionals. São Paulo, Brazil, 2018.

\begin{tabular}{|c|c|c|c|c|c|c|c|c|}
\hline \multirow{3}{*}{ Variables } & \multicolumn{2}{|c|}{ Dedication } & \multicolumn{2}{|c|}{ Absorption } & \multicolumn{2}{|c|}{ Vigor } & \multicolumn{2}{|c|}{ Overall score } \\
\hline & $\begin{array}{c}\text { Municipality } \\
\text { A }\end{array}$ & $\begin{array}{c}\text { Municipality } \\
\text { B }\end{array}$ & $\begin{array}{c}\text { Municipality } \\
\text { A }\end{array}$ & $\begin{array}{c}\text { Municipality } \\
\text { B }\end{array}$ & $\begin{array}{c}\text { Municipality } \\
\text { A }\end{array}$ & $\begin{array}{c}\text { Municipality } \\
\text { B }\end{array}$ & $\begin{array}{c}\text { Municipality } \\
\text { A }\end{array}$ & $\begin{array}{c}\text { Municipality } \\
\text { B }\end{array}$ \\
\hline & Mean ( $\pm s d)$ & Mean ( $\pm s d)$ & Mean ( $\pm s d)$ & Mean ( $\pm s d)$ & Mean ( $\pm s d)$ & Mean ( $\pm s d)$ & Mean ( $\pm s d)$ & Mean ( $\pm s d)$ \\
\hline \multicolumn{9}{|l|}{ Professional category } \\
\hline Doctor & $4.1( \pm 1.5)^{b}$ & $5.4( \pm 0.5)^{c}$ & $3.7( \pm 1.5)^{\mathrm{a}}$ & $4.5( \pm 0.7)^{\mathrm{b}}$ & $4.0( \pm 1.2)^{b}$ & $4.5( \pm 1.0)^{b}$ & $3.9( \pm 1.3)^{\mathrm{a}}$ & $4.6( \pm 0.6)^{b}$ \\
\hline Nurse & $4.4( \pm 1.2)^{\mathrm{b}}$ & $5.1( \pm 0.9)^{c}$ & $4.4( \pm 1.0)^{\mathrm{b}}$ & $4.8( \pm 1.1)^{\mathrm{b}}$ & $4.4( \pm 1.0)^{\mathrm{b}}$ & $4.7( \pm 1.2)^{\mathrm{b}}$ & $4.4( \pm 1.0)^{\mathrm{b}}$ & $4.8( \pm 1.0)^{\mathrm{b}}$ \\
\hline $\begin{array}{l}\text { Nursing Assistant/ } \\
\text { Technician }\end{array}$ & $4.4( \pm 1.3)^{a}$ & $4.7( \pm 1.2)^{\mathrm{b}}$ & $3.8( \pm 1.1)^{\mathrm{a}}$ & $4.2( \pm 1.4)^{\mathrm{b}}$ & $4.2( \pm 1.2)^{\mathrm{a}}$ & $4.6( \pm 1.2)^{b}$ & $4.1( \pm 1.1)^{\mathrm{b}}$ & $4.5( \pm 1.2)^{b}$ \\
\hline $\begin{array}{l}\text { Community } \\
\text { health agent }\end{array}$ & $3.4( \pm 1.5)^{\mathrm{a}}$ & $4.1( \pm 1.2)^{b}$ & $3.3( \pm 1.4)^{\mathrm{a}}$ & $3.8( \pm 1.0)^{\mathrm{a}}$ & $3.5( \pm 1.5)^{\mathrm{a}}$ & $4.1( \pm 0.9)^{b}$ & $3.4( \pm 1.2)^{\mathrm{a}}$ & $4.0( \pm 0.9)^{b}$ \\
\hline$p$-value & $<0.001$ & 0.007 & 0.001 & 0.042 & 0.005 & 0.215 & 0.001 & 0.028 \\
\hline \multicolumn{9}{|l|}{ Gender } \\
\hline Male & $4.1( \pm 1.6)^{\mathrm{b}}$ & $4.5( \pm 1.5)^{b}$ & $3.6( \pm 1.6)^{\mathrm{a}}$ & $4.0( \pm 1.2)^{b}$ & $4.2( \pm 1.3)^{\mathrm{b}}$ & $4.2( \pm 1.1)^{b}$ & $4.0( \pm 1.4)^{b}$ & $4.2( \pm 1.2)^{b}$ \\
\hline Female & $3.8( \pm 1.4)^{\mathrm{a}}$ & $4.7( \pm 1.1)^{\mathrm{a}}$ & $3.6( \pm 1.3)^{\mathrm{a}}$ & $4.3( \pm 1.1)^{\mathrm{b}}$ & $3.8( \pm 1.4)^{\mathrm{a}}$ & $4.4( \pm 1.0)^{\mathrm{b}}$ & $3.7( \pm 1.3)^{\mathrm{a}}$ & $4.4( \pm 1.0)^{\mathrm{b}}$ \\
\hline$p$-value & 0.331 & 0.761 & 0.973 & 0.385 & 0.161 & 0.601 & 0.388 & 0.533 \\
\hline \multicolumn{9}{|l|}{ Age group } \\
\hline $\begin{array}{l}\text { From } 18 \text { to } 28 \\
\text { years old }\end{array}$ & $3.9( \pm 1.5)^{\mathrm{a}}$ & $3.9( \pm 1.4)^{\mathrm{a}}$ & $3.7( \pm 1.2)^{\mathrm{a}}$ & $3.5( \pm 1.0)^{\mathrm{a}}$ & $3.8( \pm 1.3)^{\mathrm{a}}$ & $3.8( \pm 1.1)^{\mathrm{a}}$ & $3.8( \pm 1.2)^{\mathrm{a}}$ & $3.8( \pm 1.1) a$ \\
\hline $\begin{array}{l}\text { From } 29 \text { to } 39 \\
\text { years old }\end{array}$ & $3.7( \pm 1.5)^{\mathrm{a}}$ & $4.7( \pm 1.3)^{\mathrm{b}}$ & $3.4( \pm 1.5)^{\mathrm{a}}$ & $4.2( \pm 1.3)^{b}$ & $3.6( \pm 1.5)^{\mathrm{a}}$ & $4.4( \pm 1.0)^{b}$ & $3.6( \pm 1.4)^{\mathrm{a}}$ & $4.4( \pm 1.1)^{b}$ \\
\hline $\begin{array}{l}\text { At } 40 \text { years of age } \\
\text { or older }\end{array}$ & $4.0( \pm 1.4)^{\mathrm{b}}$ & $4.7( \pm 1.0)^{\mathrm{b}}$ & $3.9( \pm 1.3)^{\mathrm{a}}$ & $4.3( \pm 0.9)^{\mathrm{b}}$ & $4.1( \pm 1.2)^{\mathrm{b}}$ & $4.3( \pm 1.1)^{\mathrm{b}}$ & $4.0( \pm 1.2)^{\mathrm{b}}$ & $4.4( \pm 0.9)^{\mathrm{b}}$ \\
\hline$p$-value & 0.424 & 0.290 & 0.142 & 0.266 & 0.106 & 0.420 & 0.147 & 0.285 \\
\hline \multicolumn{9}{|l|}{ Time acting in PHC } \\
\hline Up to 2 years & $4.1( \pm 1.4)^{\mathrm{b}}$ & $4.5( \pm 1.5)^{\mathrm{b}}$ & $3.9( \pm 1.3)^{\mathrm{a}}$ & $3.9( \pm 1.2)^{\mathrm{a}}$ & $4.1( \pm 1.3)^{b}$ & $4.4( \pm 1.0)^{\mathrm{b}}$ & $4.0( \pm 1.3)^{\mathrm{b}}$ & $4.3( \pm 1,2)^{b}$ \\
\hline $\begin{array}{l}\text { From } 3 \text { to } 10 \\
\text { years }\end{array}$ & $3.6( \pm 1.5)^{\mathrm{a}}$ & $4.6( \pm 1.1)^{b}$ & $3.4( \pm 1.5)^{\mathrm{a}}$ & $4.2( \pm 1.1)^{b}$ & $3.6( \pm 1.4)^{\mathrm{a}}$ & $4.3( \pm 1.0)^{b}$ & $3.5( \pm 1.4)^{\mathrm{a}}$ & $4.3( \pm 1.0)^{\mathrm{b}}$ \\
\hline Above 10 years & $3.8( \pm 1.5)^{\mathrm{a}}$ & $4.9( \pm 0.9)^{b}$ & $3.6( \pm 1.4)^{\mathrm{a}}$ & $4.5( \pm 1.2)^{b}$ & $3.9( \pm 1.4)^{\mathrm{a}}$ & $4.6( \pm 1.2)^{b}$ & $3.8( \pm 1.3)^{\mathrm{a}}$ & $4.7( \pm 1.0)^{\mathrm{b}}$ \\
\hline$p$-value & 0.136 & 0.620 & 0.094 & 0.411 & 0.039 & 0.540 & 0.056 & 0.559 \\
\hline
\end{tabular}

Source: Research data. sd: standard deviation. ${ }^{a}$ Medium level of engagement. ${ }^{b}$ High level of engagement. ${ }^{c}$ Very High level of engagement.

health, which favor the work of the teams and improve the effectiveness and resilience of the FHS, in meeting the demands of the population.

The literature indicates that professionals with high levels of engagement have better work performance, because they present better health levels, experience positive emotions more frequently, create their own personal resources and are able to transfer engagement to other professionals. ${ }^{27}$

The difference in levels of engagement among municipalities, with a higher number of lower scores among professionals from the large municipality, corroborate the Brazilian literature, which indicates average levels among medical residents ${ }^{18}$, and higher levels among workers from different regions of Brazil, with age over 40 years. $^{9}$
Besides that, the differences observed suggest that professionals from municipalities where FHS is not established throughout the territory, but only in peripheral communities, socioeconomically disadvantaged and with a higher disease burden, tend to have lower levels of engagement as a result of adverse working conditions.

In Brazil, regional socioeconomic and health inequalities and the shortage of qualified professionals make it difficult to structure Family Health teams, make it difficult to establish professionals in remote and less favored areas, and contribute to the turnover of professionals. ${ }^{26,28}$

Nevertheless, the results observed in this study among the professionals of the small municipality, corroborate findings of a study with health professionals (nurses, doctors, 
physiotherapists, psychologists and radiologists) of the interiornorth of Portugal, who presented higher levels of engagement than the professionals of large Portuguese cities. ${ }^{29}$

Considering that engaged professionals, because they identify themselves with the work, dedicate more effort during the work activity ${ }^{30}$, these results reinforce the necessity and importance of implementing strategies that promote the engagement among PHC professionals, giving them better conditions to face the adversities and high labor demands ${ }^{31}$ and favoring the increase of the creativity and the resoluteness of the primary care services.

\section{CONCLUSIONS AND IMPLICATIONS FOR THE PRACTICE}

The study showed that professionals from a municipality in which FHS was fully implanted tend to have higher levels of engagement. Nurses presented significantly higher levels of engagement, while community health agents reached lower levels than other professionals did.

The results show that engagement is an important indicator of workers' mental well-being and contributes to the evaluation of the workforce in PHC services. In this way, it can be used by the managers to direct strategies that improve the levels of dedication, absorption and vigor of these workers, benefiting the organization of the Health System in the first level of attention.

By achieving a high level of energy and strong identification with work, the Family Health Teams' workforce will converge to build a comprehensive, robust and effective health care system that can fully meet the precepts of PHC.

As a limitation of the study, it is worth noting the constitution of the sample in two municipalities in São Paulo, being necessary to carry out new studies with professionals from municipalities in other regions of Brazil, in order to compare the levels of engagement in professionals inserted in other realities from those found in the municipalities of the study, deepening the discussion about the theme.

\section{REFERENCES}

1. Giovanella L, Mendonça MHM, Almeida PF, Escorel S, Senna MCM, Fausto MCR, et al. Family health: limits and possibilities for an integral primary healthcare approach in Brazil. Ciênc Saúde Coletiva [Internet] 2009 jun; [cited 2019 may 04]; 14(3):783-94. Available from: http://dx.doi. org/10.1590/S1413-81232009000300014

2. Silva LA, Casotti CA, Chaves SC. Brazilian scientific production on the Family Health Strategy and the change in the model of care. Ciênc Saúde Coletiva [Internet]. 2013 jan; [cited 2019 may 04]; 18(1):221-32. Available from: http://dx.doi.org/10.1590/S1413-81232013000100023

3. Escorel S, Giovanella L, Mendonça MHM, Senna MCM. The Family Health Program and the construction of a new model for primary care in Brazil. Rev Panam Salud Publica [Internet]. 2007 feb/mar; [cited 2019 may 04];21(2-3):164-76. Available from: https://www.ncbi.nlm.nih.gov/ pubmed/17565803
4. Ministério da Saúde (BR). Portaria n. 2.436, de 21 de setembro de 2017. Aprova a Política Nacional de Atenção Básica, estabelecendo a revisão de diretrizes para a organização da Atenção Básica, no âmbito do Sistema Único de Saúde (SUS). Diário Oficial da União [Internet]. Brasília (DF): Ministério da Saúde. 22 set 2017; [cited 2018 jun 12] Available from: http://pesquisa.in.gov.br/imprensa/jsp/visualiza/index. jsp?data $=22 / 09 / 2017$ \& jornal $=1$ \&pagina $=68 \&$ totalArquivos $=120$

5. Ministério da Saúde (BR). Secretaria de Atenção à Saúde. Departamento de Atenção Básica. Política Nacional de Atenção Básica [Internet] $4^{\text {a }}$ ed. Brasília (DF): DAB/SAS/Ministério da Saúde. 2006; [cited 2019 may 04]. Available from: http://bvsms.saude.gov.br/bvs/publicacoes/ politica_nacional_atencao_basica_4ed.pdf

6. Campos GW, Barro RB, Castro AM. Evaluation of national policy of health promotion. Ciênc Saúde Coletiva [Internet]. 2004 set; [cited 2019 may 04]; 9(3):745-49. Available from: http://dx.doi.org/10.1590/ S1413-81232004000300025

7. Schaufeli WB. What is engagement?. In: Soane E, Alfes K, Truss C, Shantz A, editors. Employee engagement in theory and practice. London: Routledge; 2014. p.15-35.

8. Schaufeli WB, Dijkstra P, Vazquez AC. Engajamento no trabalho. São Paulo: Casa do Psicólogo; 2013.

9. Vazquez ACS, Magnan ES, Pacico JC, Hutz CS. Normatization of the Brazilian Utrecht Work Engagement Scale. Aval Psicol [Internet] 2016 ago; [cited 2019 may 04]; 15(2):133-40. Available from: http:// pepsic.bvsalud.org/scielo.php?script=sci_arttext\&pid=S167704712016000200002\&lng=pt

10. Bakker $A B$, Leiter MP. Where to go from here: integration and future research on work engagement. In: Bakker AB, Leiter MP, editors. Work Engagement: a handbook of essential theory and research. New York: Psychology Press; 2010. p.181-96.

11. Porto-Martins PC, Basso-Machado PG, Benevides-Pereira AMT. Work engagement: a theoric discussion. Fractal, Rev Psicol [Internet]. 2013 dez; [cited 2019 may 04]; 25(3):629-44. Available from: https://dx.doi. org/10.1590/S1984-02922013000300013

12. Salanova M, Schaufeli WB. El engagement en el trabajo. Madrid: Alianza Editorial; 2009.

13. Bakker AB. An evidence-based model of work engagement. Current Directions in Psychological Science [Internet]. 2011 aug [cited 2019 may 04]; 20(4):265-69. Available from: https://doi org/10.1177/0963721411414534

14. Schaufeli W, Bakker AB. Escala de Engagement no Trabalho de Utrecht - Manual [Internet]. Tradução de Agnst R, Benevides-Pereira AMT, PortoMartins PC. Curitiba: GEPEB; 2009; [cited 2019 may 04]. Available from https://www.wilmarschaufeli.nl/publications/Schaufeli/Test\%20Manuals/ Test_manual_UWES_Brazil.pdf

15. Maio TM. Bullying e Engagement em Enfermeiros [dissertação] [Internet]. Porto: Escola Superior de Enfermagem do Porto; 2016; [cited 30 mar 2019]. Available from: http://hdl.handle.net/10400.26/17531

16. Cordioli DFC, Junior JRC, Gazzeta CE, Silva AG, Lourenção LG Occupational stress and work engagement in primary health care workers. Rev Bras Enferm [Internet]. 2019;72(6):no prelo 2019.

17. Silva AG. Níveis de engagement em enfermeiros da atenção primária à saúde [dissertação] [Internet]. São José do Rio Preto: Faculdade de Medicina de São José do Rio Preto;2018; [cited 2019 may 04]. Available from: http://hdl.handle.net/tede/443

18. Teixeira PR, Lourenção LG, Gazetta CE, Gonsalez EG, Rotta DS Pinto $\mathrm{MH}$, et al. Engagement no trabalho em residentes médicos de pediatria. Rev Bras Educ Med [Internet]. 2017 jan; [cited 2017 ju 14]; 41(1):126-33. Available from: http://dx.doi.org/10.1590/1981$52712015 \mathrm{v} 41 \mathrm{n} 1 \mathrm{rb} 20160039$

19. Merino CF, Gallardo RY. Describing the engagement in primary health care nurses. Cienc Enferm [Internet]. 2014; [cited 2018 feb 12]; 20(3):131-40. Available from: https://scielo.conicyt.cl/scielo. php?script=sci_arttext $\&$ pid=S0717-95532014000300012 
20. Vazquez ACS, Magnan ES, Pacico JC, Hutz CS, Schaufeli WB. Adaptation and Validation of the Brazilian Version of the Utrecht Work Engagement Scale. Psico-USF [Internet]. 2015 may/aug; [cited 2019 may 04];20(2):207-17. Available from: https://dx.doi.org/10.1590/141382712015200202

21. Kanno NP, Bellodi PL, Tess BH. Family Health Strategy professionals facing medical social needs: difficulties and coping strategies. Saude Soc [Internet]. 2012 dez; [cited 2019 may 04]; 21(4):884-94. Available from: http://dx.doi.org/10.1590/S0104-12902012000400008

22. Freeney $Y$, Fellenz MR. Work engagement, job design and the role of the social context at work: Exploring antecedents from a relational perspective. Hum Relat [Internet]. 2013 jun; [cited 2019 may 04]; 66(11):142745. Available from: https://doi.org/10.1177/0018726713478245

23. Santos LPGS, Fracolli LA. Community health aides: possibilities and limits to health promotion. Rev Esc Enferm USP [Internet]. 2010 mar; [cited 2019 may 04]; 44(1):76-83. Available from: http://dx.doi. org/10.1590/S0080-62342010000100011

24. Lourenção LGL, Back CR, Santos CB, Sousa CP. Qualidade de vida de agentes comunitários de saúde de um município do interior do Estado de São Paulo. Arq Ciênc Saúde [Internet]. 2012 jan/mar; [cited 2019 may 04]; 19(1):19-27. Available from: http://repositorio-racs.famerp.br/ racs_ol/vol-19-1/IDW\%203\%20-\%20JAN\%20-\%20MAR\%202012.pdf

25. Wai MFP, Carvalho AMP. O trabalho do agente comunitário de saúde: fatores de sobrecarga e estratégias de enfrentamento. Rev Enferm UERJ [Internet]. 2009 out/dez; [cited 2019 may 04]; 17(4):563-8. Available from: http://www.facenf.uerj.br/v17n4/v17n4a19.pdf
26. Giovanella L, Mendonça MHM, Fausto MCR, Almeida PF, Bousquat A Lima JG, et al. Emergency supply of doctors by the Mais Médicos (More Doctors) Program and the quality of the structure of primary health care facilities. Ciênc Saúde Coletiva [Internet]. 2016 set; [cited 2019 may 04]; 21(9):2697-2708. Available from: http://dx.doi.org/10.1590/141381232015219.16052016

27. Bakker AB, Demerouit B. Towards a model of work engagement. Career Dev Int [Internet]. 2008; [cited 2019 may 04]; 13(3):209-23. Available from: https://www.isonderhouden.nl/doc/pdf/arnoldbakker/articles/ articles_arnold_bakker_164.pdf

28. Seidl H, Vieira SP, Fausto MCR, Lima RCD, Gagno J. Gestão do trabalho na Atenção Básica em Saúde: uma análise a partir da perspectiva das equipes participantes do PMAQ-AB. Saúde Debate [Internet]. 2014 oct; [cited 2019 may 04]; 38(spe):94-108. Available from: http:// dx.doi.org/10.5935/0103-1104.2014S008

29. Silva M, Queirós C, Cameira M, Vara N, Galvão A. Burnout and Engagement among health professionals from interior: north of Portugal. Psic., Saúde \& Doenças [Internet]. 2015 dec; [cited 2019 may 04]; 16(3):286-99. Available from: http://www.scielo.mec.pt/scielo. php?script=sci_arttext\&pid=S1645-00862015000300002\&lng=en

30. Siqueira MMM, Martins MCF, Orengo V, Souza W. Engajamento no trabalho. In: Siqueira MMM, organizador. Novas medidas do comportamento organizacional: ferramentas de diagnóstico e gestão. Porto Alegre: Artmed; 2014. p.147-56.

31. Bakker AB. An evidence-based model of work engagement. Curr Dir Psychol Sci [Internet]. 2011 aug; [cited 2019 may 04]; 20(4):265-9. Available from: https://doi.org/10.1177/0963721411414534 